\title{
KEMATIAN TAHANAN DI RUANG SEL POLISI KONTROVERSI PEMBUNUHAN ATAU BUNUH DIRI DILIHAT DARI SUDUT PANDANG ILMU KEDOKTERAN FORENSIK
}

\author{
Rika Susanti \\ Bagian Forensik dan Medikolegal Fakultas Kedokteran Universitas Andalas \\ email : rikasusanti1976@yahoo.com
}

\section{Abstrak}

Kematian tahanan cukup sering ditemukan, beberapa cara mati dapat terjadi. Kasus yang banyak adalah cara mati dengan bunuh diri. Tugas dokter dalam menangani kasus kematian yang diotopsi adalah untuk menentukan sebab mati dan mekanisme mati, sedangkan cara mati adalah kewenangan penyidik. Pada kematian akibat asfiksia mekanik, akan ditemukan ciri umum yang sama, tetapi dokter dapat memperkirakan jenis asfiksia dari gambaran luka yang ditemukan tubuh korban.

Dua kakak beradik, laki-laki, umur masing-masing 18 tahun dan 15 tahun ditemukan dalam keadaan tergantung di runag tahanan polisi. Otopsi dilakukan antara 24-48 jam post mortem. Pada pemeriksaan ditemukan luka lecet tekan dengan pola sesuai kasus gantung dileher dan beberapa luka lecet dan memar dianggota gerak terutama anggota gerak bawah. Kuku berwarna keunguan, daerah leher dan wajah berwarna lebih gelap. Tubuh kedua korban sudah mulai membusuk. Pada pemeriksaan dalam ditemukan memar pada otot leher, tanda-tanda mati lemas pada beberapa organ, sedangkan pada bagian tubuh lain tidak ditemukan tanda-tanda kekerasan.

Sebab kematian kekerasan tumpul dileher karena ditemukan tanda-tanda intravitalitas luka, dan tanda- tanda asfiksia pada tubuh korban, pola luka dileher sesuai pola gantung. Tidak ditemukan tanda kekerasan lain yang bisa menyebabkan kematian. Beberapa luka lecet dengan umur yang berbeda-beda ditemukan di ekstremitas hal ini bisa disebabkan oleh berbagai kekerasan tumpul. Kasus ini menjadi kontroversi karena kematian di tahanan dianggap ada kelalain petugas, dan korban adalah usia anak dan kakak beradik.

Kata kunci : kematian di tahanan-asfiksis mekanik-cara mati

\section{Abstract}

Death of prisoner quite often find in several methods. The most case of death are by suicide method. Physician role in autopsy is to found cause of death and death mechanism, whereas death method is authority of investigating officer. Death caused by mechanical asphyxia will find the same general characteristic, but physician can estimated kind of asphyxia from wound appearance in victim body. 
Two siblings, boys, 18 years old and 15 years old, have found in hanging position in prison. Autopsy has done between 24-48 hours postmortem. In examination, we find pressure abrasion wound in pattern appropriate with hanging case in neck and some of abrasion and bruise wound in extremity, especially inferior extremity. Nails color are purplish, color of neck and face are darker. Victim body has started to decay. In inside examination, we find bruise in neck muscle, shown evidence of dead cause asphyxia in some organs, whereas in other part of body did not find sign of force.

Cause of death is blunt wound in neck because we find a sign of intra-vitality injury and asphyxia sign in victim body, pattern of wound in neck are appropriate hanging pattern. We did not find other force sign which cause a death. Some of abrasion wound with different age find in extremity, and this case can caused by many blunt wound.

This case be a controversial because death in prison considered by dereliction of officer, and as we know, victim are children and sibling.

Key word: Death in prisoner-asphyxia-dead method 


\section{Pendahuluan}

Asfiksia adalah kumpulan dari berbagai keadaan dimana terjadi gangguan dalam pertukaran udara pernafasan yang normal. Afiksia mekanik adalah mati lemas yang terjadi bila udara pernafasan terhalang memasuki saluran pernafasan oleh berbagai kekerasan (yang bersifat mekanik). Gangguan ini akan menimbulkan suatu keadaan dimana oksigen dalam darah berkurang yang disertai dengan peningkatan kadar karbondioksida. Keadaan ini jika terus dibiarkan dapat menyebabkan terjadinya kematian. Asfiksia merupakan penyebab kematian terbanyak yang ditemukan dalam kasus kedokteran forensik. Asfiksia mekanik yang cukup banyak adalah penggantungan (hanging). Hanging sering dilakukan dalam usaha bunuh diri, tetapi ada juga pembunuhan dengan cara korban digantung. ${ }^{(1-6)}$

Pada tahun 2003, WHO mengungkapkan bahwa satu juta orang bunuh diri setiap tahunnya atau satu orang setiap 40 detik. Bunuh diri merupakan satu dari tiga penyebab utama kematian pada usia 15 - 34 tahun, selain karena kecelakaan. Menurut WHO, pada tahun 2005 sedikitnya 50.000 orang Indonesia melakukan bunuh diri dan diperkirakan 150 orang di Indonesia melakukan bunuh diri setiap hari. ${ }^{(7-9)}$ Menurut data dari Kepolisian Daerah Metro Jaya selama 2003 tercatat 62 kasus bunuh diri. Jumlah ini merupakan kelipatan tiga kali lebih banyak dari pada angka tahun 2002. Sedangkan untuk tahun 2004, Kompas mencatat setidaknya 38 kasus bunuh diri sampai pertengahan Juni ini. Menurut data dari Polda Metro, usia korban sangat bervariasi, mulai dari belasan hingga 65 tahun. Angka bunuh diri di Jakarta sepanjang tahun 1995 2004 mencapai 5,8 per 100.000 penduduk. Mayoritas dilakukan oleh kaum pria. Dari 1.119 korban bunuh diri, $41 \%$ di antaranya gantung diri, 23\% dengan minum racun dan 356 orang sisanya karena overdosis obat terlarang. Gantung diri merupakan cara kematian yang paling sering dijumpai pada penggantungan, yaitu sekitar $90 \%$ dari seluruh kasus. ${ }^{(1-5)}$

\section{Kematian di tahanan}

Semua cara kematian bisa saja terjadi pada korban yang dipenjara/tahanan. Penghuni penjara/tahanan memiliki tingkat lebih tinggi bunuh diri daripada populasi umum. Dalam penjara/tahanan, risiko bunuh diri meningkat karena sifat transien dari populasi dan fakta bahwa penjara/tahanan adalah sebuah pengalaman baru bagi mereka. Beberapa studi menyatakan bahwa korban bunuh diri adalah pelaku kejahatan tanpa kekerasan. Penelitian lain juga menyebutkan penangkapan dengan kekerasan dan hukuman penjara yang lama merupakan stressor yang mungkin terjadi. Suatu penelitian mendapatkan setidaknya $75 \%$ dari korban memiliki riwayat psikiatris. $^{(2)}$

Bunuh diri di penjara/tahanan paling banyak terjadi dalam 1 sampai 2 hari penahanan. Dalam sebuah penelitian di Texas, setidaknya setengah dari korban bunuh diri dipenjara telah melakukan upaya bunuh diri sebelumnya, sekitar dua pertiga telah membuat setidaknya satu upaya selama penahanan mereka, dan sekitar dua pertiga memiliki riwayat penyalahgunaan alkohol dan obat terlarang lainnya. ${ }^{(2)}$

Mayoritas (60\%) dari tahanan di sebuah penelitian di Inggris bunuh diri dalam 3 bulan pertama penahanan. Penelitian telah menunjukkan bahwa bunuh diri dengan cara gantung diri banyak terjadi antara tengah malam dan 
pagi, ketika pengawasan berkurang. Beberapa kasus bunuh diri terjadi pada siang hari dengan harapan oleh korban bahwa resusitasi segera oleh staf dimungkinkan. Kebanyakan korban adalah laki-laki dan usia terbanyak kurang dari 35 tahun yang mencerminkan populasi penjara umum. Berbagai cara misalnya overdosis, pemotongan, melompat, pencekikan digunakan, tetapi gantung diri adalah yang paling sering. Kematian di penjara-penjara memerlukan penyelidikan yang hati hati dan otopsi menyeluruh, terutama karena tuduhan pembunuhan publik terhadap pihak berwenang atau kritik terhadap kegagalan mereka untuk mengenal narapidana yang berpotensial bunuh diri. $^{(2)}$

\section{Dasar Hukum}

Dalam penyidikan untuk kepentingan peradilan menangani seorang korban yang diduga karena peristiwa tindak pidana, seorang penyidik berwenang mengajukan permintaan keterangan ahli kepada ahli kedokteran kehakiman atau dokter dan atau ahli lainnya. Seorang dokter sebagaimana pasal 179 KUHAP wajib memberikan keterangan yang sebaik-baiknya dan yang sebenarnya menurut pengetahuan di bidang keahliannya demi keadilan.

Ketentuan tentang bantuan dokter untuk kepentingan peradilan didalam KUHAP tercantum didalam pasal 133 dan 179 dan 180.

\section{Asfiksia Mekanik}

Asfiksia merupakan mekanisme kematian, maka secara menyeluruh untuk semua kasus asfiksia mekanik akan ditemukan tanda-tanda umum yang hampir sama, yaitu pada pemeriksaan luar, muka dan ujungujung ekstremitas sianotik (warna biru keunguan) yang disebabkan tubuh mayat lebih membutuhkan $\mathrm{HbCO}_{2}$ daripada $\mathrm{HbO}_{2}$. Tardieu's spot. Tardieu's spot merupakan bintik-bintik perdarahan (petekie) akibat pelebaran kapiler darah setempat. Lebam mayat cepat timbul, luas, dan lebih gelap karena terhambatnya pembekuan darah dan meningkatnya fragilitas/permeabilitas kapiler. Hal ini akibat meningkatnya kadar $\mathrm{CO}_{2}$ sehingga darah dalam keadaan lebih cair. Lebam mayat lebih gelap karena meningkatnya kadar $\mathrm{HbCO}_{2}$. Busa halus keluar dari hidung dan mulut. Busa halus ini disebabkan adanya fenomena kocokan pada pernapasan kuat. ${ }^{(1,4-6,11)}$

Sedang pada pemeriksaan dalam akan ditemukan organ dalam tubuh lebih gelap \& lebih berat dan ejakulasi pada mayat laki-laki akibat kongesti/bendungan alat tubuh \& sianotik. Darah berwarna gelap dan lebih cair. Tardieu's spot pada pielum ginjal, pleura, perikard, galea apponeurotika, laring, kelenjar timus dan kelenjar tiroid. Busa halus di saluran pernapasan.Edema paru dan kelainan lain yang berhubungan dengan kekerasan seperti fraktur laring, fraktur tulang lidah dan resapan darah pada luka. ${ }^{(1,4,11)}$

\section{Penggantungan (Hanging)}

Penggantungan (hanging) meru-

pakan suatu strangulasi berupa tekanan pada leher akibat adanya jeratan yang menjadi erat oleh berat badan korban. Temuan pada pemeriksaan luar pada daerah kepala : Muka korban penggantungan akan mengalami sianosis dan terlihat pucat karena vena terjepit. Selain itu, pucat pada muka korban juga disebabkan terjepitnya arteri. Mata korban dapat melotot akibat adanya bendungan pada kepala korban. Hal ini disebabkan terhambatnya venavena kepala tetapi arteri kepala tidak terhambat. Bintik-bintik perdarahan 
pada konjungtiva korban terjadi akibat disebut penggantungan parsial. Bahan pecahnya vena dan meningkatnya yang digunakan biasanya tali, ikat permeabilitas pembuluh darah karena pinggang, kain, dll. ${ }^{(1,4,6,12)}$

asfiksia. Lidah korban penggantungan bisa terjulur, bisa juga tidak terjulur. Lidah terjulur apabila letak jeratan gantungan tepat berada pada kartilago tiroidea. Lidah tidak terjulur apabila letaknya berada diatas kartilago tiroidea. Pada daerah leher alur jeratan pada leher korban penggantungan berbentuk lingkaran (V shape). Anggota gerak (lengan dan tungkai) ditemukan lebam mayat pada ujung bawah lengan dan tungkai. Dubur dapat mengeluarkan fesesdan alat kelamin dapat mengeluarkan mani, urin. Lebam mayat dapat ditemukan pada genitalia eksterna. ${ }^{(1,4,6,12)}$

\section{Laporan Kasus}

Pada tanggal dua puluh sembilan Desember tahun dua ribu sebelas, sekitar pukul dua puluh dua Waktu Indonesia Bagian Barat, dilakukan otopsi terhadap dua korban kakak beradik,laki - laki, berumur 15 tahun dan 18 tahun. Dasar dilakukan otopsi adalah surat permintaan visum et repertum dari kepolisian Resor Sijunjung tertanggal dua puluh delapan Desember tahun dua ribu sebelas. Korban ditemukan meninggal dalam keadaan tergantung di ruang tahanan polisi. Pemeriksaan dilakukan sekitar

Pemeriksaan dalam, dapat kita temukan tanda-tanda bendungan pembuluh darah otak. Pada leher dapat temukan adanya perdarahan dalam otot atau jaringan, fraktur (os hyoid, kartilago tiroidea, kartilago krikoidea, dan trakea), dan robekan kecil pada intima pembuluh darah leher (vena jugularis). Pada dada dan perut korban dapat ditemukan adanya perdarahan (pleura, perikard, peritoneum, dan lainlain) dan bendungan/kongesti organ. Darah dalam jantung korban penggantungan (hanging) warnanya lebih gelap dan konsistensinya lebih cair.

Posisi korban pada kasus gantung diri bisa bermacam-macam, kemungkinan tersering adalah kedua kaki tidak menyentuh lantai (complete hanging) dan duduk berlutut (biasanya menggantung pada daun pintu). Untuk posisi ini ada yang menyebutkan dengan istilah penggantungan parsial. Istilah ini digunakan jika beban berat badan tubuh tidak sepenuhnya menjadi kekuatan daya jerat tali. Pada kasus tersebut berat badan tubuh tidak seluruhnya menjadi gaya berat sehingga 24-48 jam post mortem. Menurut keterangan keluarga, kedua kaki korban menyentuh lantai. Pada perkembangan kasus ini, pihak keluarga menyangkal bahwa kedua korban mati dengan cara bunuh diri. Keluarga menduga kematian korban akibat pembunuhan.

\section{Hasil pemeriksaan I:}

Korban Laki-laki, usia 15 tahun ditemukan pakaian mayat tidak ada, gigi geligi lengkap dua puluh delapan buah, lebam mayat terdapat pada bagian punggung berwarna keunguan gelap, tidak hilang pada penekanan, dari lubang hidung keluar cairan berwarna merah kehitaman. Pada tubuh ditemukan tanda - tanda pembusukan. Jaringan dibawah kuku berwarna keunguan dan pada daerah leher dan wajah berwarna lebih gelap. Pada tubuh korban ditemukan luka - luka : Pada leher terdapat luka lecet tekan yang melingkari leher yang berjalan dari dari bawah depan ke atas belakang dengan lebar lebih kurang delapan millimeter dan luka menghilang pada bagian belakang. Pada paha kanan ditemukan beberapa luka memar berwarna merah 
kebiruan.Pada tungkai bawah kiri ditemuka dua buah luka lecet.

\section{Pada pemeriksaan}

dalam

ditemukan resapan darah pada otot dan jaringan bawah kulit leher, bintik perdarahan pada permukaan jantung dan paru. Kulit kepala, tulang tengkorak dan otak tidak ada tanda-tanda kekerasan.

\section{Hasil pemeriksaan II}

Korban laki-laki, usia 18 tahun ditemukan pakaian tidak ada, lebam mayat pada punggung berwarna keunguan gelap, tidak hilang pada penekanan, gigi geligi berjumlah dua puluh empat buah, rahang kanan atas jumlah gigi lima buah, gigi pertama dan kedua tidak ada. Rahang kiri atas jumlah gigi enam buah, gigi ketiga tidak ada. Rahang kanan bawah jumlah gigi enam buah. Rahang kiri bawah jumlah gigi enam buah, gigi ketiga tidak ada. Dari lubang hidung keluar cairan warna merah kehitaman. Pada tubuh ditemukan tanda - tanda pembusukan. Jaringan dibawah kuku berwarna keunguan dan pada daerah leher dan wajah berwarna lebih gelap. Luka - luka pada tubuh korban : Pada leher terdapat luka lecet tekan yang melingkari leher yang berjalan dari depan bawah ke belakang atas dengan lebar lebih kurang satu sentimeter, menghilang pada bagian belakang. Pada lengan kanan terdapat luka lecet, pada paha terdapat satu buah luka lecet dan pada tungkai bawah terdapat enam buah luka lecet ada yang berwarna kehitaman dan ada berwarna merah kehitaman. Punggung kaki kiri terdapat luka lecet dan pada ibu jari kaki kiri terdapat resapan darah.

Pada pemeriksaan dalam ditemukan resapan darah pada otot dan jaringan ikat kulit dibawah leher, pada permukaan jantung dan paru ditemukan bintik perdarahan sedangkan kulit kepala bagian dalam, tulang tengkorak dan otak tidak ditemukan tanda - tanda kekerasan.

\section{Pembahasan Kasus}

\section{Aspek Hukum Pengadaan Visum et Repertum}

Dasar hukum pembuatan visum et repertum adalah pasal 133 KUHAP, yaitu bila yang diperiksa adalah manusia sebagai korban atau diduga sebagai korban suatu tindak pidana, baik masih hidup ataupun sudah mati.

Pasal 133 KUHAP :

1) Dalam hal penyidik untuk kepentingan peradilan menangani seorang korban baik luka, keracunan ataupum mati yang diduga karena peristiwa yang merupakan tindak pidanan, ia berwenang mengajukan permintaan keterangan ahli kepada ahli kedokteran kehakiman atau dokter dan atau ahli lainnya.

2) Permintaan keterangan ahli sebagaimana dimaksud dalam ayat (1) dilakukan secara tertulis, yang dalam surat itu disebutkan dengan tegas untuk pemeriksaan luka atau pemeriksaan mayat dan atau pemeriksaan bedah mayat.

3) Mayat yang dikirim kepada ahli kedokteran kehakiman atau dokter pada rumah sakit harus diperlakukan secara baik dengan penuh penghormatan terhadap mayat tersebut dan diberi label yang memuat identitas mayat, dilak dengan diberi cap jabatan yang dilekatkan pada ibu jari kaki atau bagian lain badan mayat.

Dasar hukum pemeriksaan kedua korban telah memenuhi pasal 133 KUHAP ayat 1 dan 2 dengan adanya surat permintaan visum dari Kepolisian 
Resor Sijunjung. Sedangkan adanya ketentuan mengenai mayat yang harus diberi label belum terpenuhi pada kasus ini. Pemberian label di wilayah Sumatera Barat pada umumnya belum dibiasakan, mungkin penyidik beranggapan karena mayat yang ada dikamar jenazah RS tidak terlalu banyak dan kemungkinan untuk tertukar hampir tidak ada.

\section{Temuan pada Jenazah}

Pada kedua jenazah, ditemukan lebam pada punggung berwarna keunguan gelap yang tidak hilang pada penekanan. Hal ini bisa menjelaskan bahwa kematian jenazah sudah lebih dari delapan sampai dua belas jam, hal ini juga didukung dengan ditemukannya tanda pembusukan pada kedua jenazah. Lebam mayat dengan posisi dipunggung menggambarkan bahwa mayat berada pada posisi telentang. Pada posisi mayat tergantung lebam biasanya ditemukan diujung ujung ekstremitas dan genitalia eksterna. Pada kedua mayat lebam hanya ditemukan di punggung. Hal ini bisa dijelaskan bahwa mayat ditemukan dalam keadaan tergantung pada waktu kurang dari delapan jam, pada saat itu mungkin ada lebam pada ujung ekstremitas dan genitalia eksterna, tetapi dengan dirubahnya posisi menjadi tidur telentang maka akan terbentuk lebam baru pada punggung dan lebam lama berangsur - angsur turun ke bawah. Lebam berwarna lebih gelap disebabkan karena tingginya kadar $\mathrm{CO} 2$ didalam darah. Cairan merah kehitaman yang keluar dari hidung bisa akibat cairan karena proses perbendungan yang keluar atau bisa juga cairan pembusukan.

Pada kedua korban ditemukan daerah leher dan wajah berwarna lebih gelap. Hal ini disebabkan karena proses perbendungan pada vena di daerah leher, sehingga darah terhambat untuk balik ke jantung dan memberikan gambaran kulit leher dan wajah berwarna lebih gelap

Jaringan dibawah kuku berwarna keunguan. Hal ini merupakan tanda sianosis. Warna kebiru-biruan yang terdapat pada kulit dan selaput lendir terjadi akibat peningkatan jumlah absolute hemoglobin tereduksi ( $\mathrm{Hb}$ yang tidak berikatan dengan O2).

Gambaran luka, pada kedua korban ditemukan luka lecet tekan pada leher yang berjalan dari depan bawah ke belakang atas dan menghilang pada bagian belakang. Pada daerah leher dan dagu tidak ditemukan adanya tanda kekerasan/luka yang mengarah kepada luka perlawanan ataupun luka karena kekerasan lain.

Luka pada leher adalah luka akibat kekerasan tumpul, diperkirakan luka akibat alat yang dipakai untuk mengikat leher. Dari gambaran luka lecet tekan dileher tidak memberikan pola/gambaran yang khas, hal ini mungkin diakibatkan karena luka dileher akibat benda dengan permukaan yang licin (tidak berpola) dan dengan permukaan yang cukup lebar. Luka diperkirakan terjadi intravital yaitu pada saat korban masih hidup dengan alasan bahwa pada korban ditemukan adanya tanda - tanda asfiksia seperti perbendungan di daerah leher dan wajah, tanda sianosis pada jaringan dibawah kuku. Menurut pola dan gambaran luka yang ditemukan diperkirakan luka yang terjadi pada kasus gantung, dengan simpul berada dibelakang. Sebagai dokter kita bisa membedakan luka di leher apakah polanya gantung atau jerat. Dimana perbedaan keduanya adalah jika pola gantung : luka berjalan dari bawah ke atas menuju simpul, luka berada diatas jakun dan menghilang pada sisi tertentu dan biasanya tidak ditemukan adanya luka lain pada daerah leher/ luka 
perlawanan. Sedangkan pola luka kasus jerat : luka berjalan mendatar melingkari leher, meliputi semua leher, letak lebih rendah dari jakun dan biasanya ditemukan luka lain diaerah leher yaitu luka akibat perlawanan. Dari gambaran inilah kami menyimpulkan luka pada leher adalah luka dengan pola gantung dan terjadi intravital.

Selain luka dileher, pada kedua korban ditemukan luka memar dan lecet pada ekstemitas terutama ekstremitas bawah. Adanya luka lecet/memar pada ektremitas terutama ekstremitas bawah bisa disebabkan oleh berbagai macam kekerasan tumpul. Dari gambaran luka diperkirakan ada luka yang masih baru dan ada juga yang sudah agak lama.

Dari hasil pemeriksaan dalam ditemukan luka memar pada otot dan jaringan ikat pada kulit leher, bintik perdarahan pada jantung dan paru. Adanya memar pada jaringan ikat dan otot leher disebabkan karena kekerasan yang ada dileher bagian luar yang cukup kuat untuk menimbulkan juga tanda kekerasan di bagian dalam, hal ini juga memperkuat keyakinan bahwa luka dileher adalah intravital. Pada kasus ini memang tidak ditemukan adanya tulang lidah (os hyoid) yang patah, hal ini bisa saja terjadi jika alat penjerat tidak memberikan tekanan yang kuat untuk membuat patahnya tulang lidah. Sedangkan adanya bintik perdarahan pada jantung dan paru terjadi akibat peningkatan tekanan vena secara akut sehingga menyebabkan overdistensi dan rupturnya dinding perifer vena. Biasanya terjadi pada jaringan ikat longgar seperti pada kelopak mata dan konjungtiva, permukaan jantung, paru dan otak.

\section{Kesimpulan Visum Repertum}

Pada kesimpulan hasil visum yang dijelaskan adalah sebab mati dan mekanisme mati. Pada kasus ini, pihak keluarga mempertanyakan cara mati korban. Keluarga/masyarakat menduga kematian korban adalah akibat pembunuhan. Kemungkinan yang bisa difikirkan adalah penggantungan post mortem, korban dibuat pingsang atau tidak berdaya lalu digantung. Tetapi hal ini tidak bisa dijelaskan karena pada korban tidak ditemukan luka selain di leher bisa menimbulkan kondisi diatas. Opini lain adalah korban digantung, jika digantung mestinya gambaran luka dileher diikuti dengan adanya luka lecet/luka perlawanan serta bentuk/pola luka tidak beraturan. Melihat hasil pemeriksaan kedua korban, hal ini juga tidak bisa dijelaskan. Ketika penyidik menanyakan dugaan cara mati, kita hanya bisa menjelaskan kemungkikan kemunkinan dengan memberikan alasan yang ilmiah, seperti yang sudah dijelaskan. Sampai saat ini, kasus kematian kedua kakak beradik ini masih menjadi kontreversi dikalangan keluarga dan masyarakat. Untuk memastikan cara kematian korban adalah wewenang penyidik.

\section{Kesimpulan}

Cara kematian akibat asfiksia mekanik bermacam - macam. Dokter dapat memperkirakan cara kematian dari temuan luka pada korban, akan tetapi cara kematian bukan kewenangan dokter untuk menentukan. Cara kematian merupakan kewenangan penyidik. Pada seluruh kematian akibat asfiksia mekanik ditemukan gambaran umum yang sama berupa tanda - tanda asfiksia, seperti lebam mayat berwarna lebih gelap dan luas, bintik perdarahan, perbendungan organ dan lain - lain. Pada kasus ini, didapatkan bahwa et mekanisme kematian korban adalah mati lemas akibat hambatan jalan nafas oleh kekerasan tumpul di leher. Menurut pola dan sifat luka dileher sesuai dengan pola luka gantung. Jadi 
pada kasus ini dokter tidak bisa dipaksakan untuk menentukan cara kematian korban, apakah dibunuh atau bunuh diri. Bantuan dokter hanyalah untuk menentukan sebab mati dan mekanisme mati.

\section{KEPUSTAKAAN}

1. Budiyanto A. 1997. Ilmu Kedokteran Forensik Edisi I. Jakarta. Bagian Kedokteran Forensik Fakultas Kedokteran Universitas Indonesia.

2. Forensic Pathology Of Traumacommon Problems For The Pathologist. Michael J Skhrum, MD, David A. Ramsay, MB ChB. 2007.

3. Anonim: Asfiksia. http://www.asfiksiarizsa82.wordpress.htm, diakses pada 25 April 2011.

4. Muhammad Al Fatih II. Asfiksia dalam Forensik Klinik. 2007. http://www.klinikindonesia.com /forensik.php. Diakses tanggal 26 April 2011.

5. Abdul Mun'in Idries. Pedoman Ilmu Kedokteran Forensik Edisi Pertama. Binarupa Aksara. 1997.

6. Anonim. Tanatologi Dan Identifikasi Kematian Mendadak (Khususnya Pada Kasus Penggantungan).http://fkuii.org/t ikidownload_wiki_attachment.php ?attId=14, diakses pada 26 April 2011.
7. Anonim : Bunuh Diri Di Indonesia Cukup Tinggi, 41\% Gantung Diri. http://www.bkkbn.go.id/article detail.php?aid=887, diakses pada 26 April 2011.

8. Anonim: Bunuh diri sebagai Fenomena.

http://kesehatan.blogspot.com/2 008_04_03_archive.html, diakses pada 26 April 2011.

9. Anonim: Anonim: Kasus Bunuh Diri di Gunung Kidul 95 Persen dengan Cara Gantung Diri. http://www.tempointeraktif.com /hg/nusa/jawamadura/2005/02/1 3/brk,20050213-09,id.html, diakses pada 26 April 2011.

10. Kitab Undang -Undang Hukum Acara Pidana.

11. Kitab Undang - Undang Hukum Pidana.

12. Surya Putra. Penentuan Standar Asfiksia Sebagai Penyebab Kematian di Instalasi Kedokteran Forensik RSUD DR.Sardjito. Badan Litbang Kesehatan, Departemen Kesehatan RI. Available at http://digilib.litbang.depkes.go.i d. Diakses pada 26 April 2011.

13. Shephered R. Simpson's forensic medicine. $12^{\text {th }}$ ed. London: Blackwell Publishing; 2003. Page 99-100. 